\title{
SOME REMARKS ON LAESIO ENORMIS AND PROPORTIONALITY IN ROMAN-DUTCH LAW AND CALVINISTIC COMMERCIAL ETHICS
}

\section{Jan Hallebeek ${ }^{* * *}$}

This article is dedicated to my colleague Laurens Winkel on the occasion of his retirement

\section{Introduction}

Recently the journal Ars aequi, edited by students from various legal faculties in the Netherlands, published a series of articles dealing with institutions and concepts that have their origin in Roman law or legal history and are still relevant in contemporary law. It was entitled Rode draad "Historische wortels van het recht". My contribution to this series concerned the doctrine of iustum pretium and proportionality of performances, in other words the idea that all merchandise has a fair price and that not every deviation from that price is acceptable. ${ }^{1}$ In Western legal thinking this

1 See Jan Hallebeek "De iustum pretium-leer en het evenredigheidsbeginsel” (2013) 62 Ars Aequi 59-64. The articles were collected into one volume; see Lukas van den Berge et al Historische wortels van het recht (Nijmegen, 2014).

* Professor, Department of Legal Theory and Legal History, Faculty of Law, VU University Amsterdam.

** I would like to thank Niels de Bruijn, Wim Decock and Boudewijn Sirks for their useful comments on the draft version of this paper.

\section{UNISA $\cong$}

Fundamina

Volume 21 | Number 1 | 2015

pp 14-32
Doi: $10.17159 / 2411-7870 / 2015 / v 21 n 1 a 2$ Print ISSN 1021-545X/ Online ISSN 2411-7870

(C) Unisa Press 
principle has played, and still plays, a predominant role, which was, for example, acknowledged in Roman-Dutch law. ${ }^{2}$ In the Dutch Civil Code of 1838, however, the principle was rejected (art 1486), as it was in the French Code civil of 1804 (art 1118), although the latter did acknowledge an exception. The seller of immovable property was protected when the selling price was lower than five-twelfths (5/12) of the fair price (arts 1674-1685 Code civil). The Dutch legislature decided not to adopt this exception. According to the government, there was no need to do so, since considerable prejudice would anyway include deceit. ${ }^{3}$ In the nineteen thirties, some jurists nevertheless defended the proposition that an approximate equivalence of performances should be a cornerstone of the Dutch law of contract. ${ }^{4}$ This opinion remained a minority view, while the new Civil Code of 1992 did not make any substantive changes. The principle of proportionality is not acknowledged in the Code and, according to the prevailing view, is no longer in force. ${ }^{5}$

The reason for returning so promptly to the subject is that my conclusions in respect of Roman-Dutch law seemed to be incompatible with some sources referred to and interpreted in an article on the role of Roman law in early modern commerce. This article, entitled "The moral menace of Roman law and the making of commerce: Some Dutch evidence", was published in 1996 by James Whitman (b 1957) of the Yale Law School. ${ }^{6}$ In this contribution, I would like to make a more intensive study of the material canvassed in this article and of Whitman's suggestion that there might have been a clash between two approaches to fair pricing, namely the traditional Christian one on the one hand, and that of the jurists and clergymen of the Dutch Republic on the other. Before turning to the early modern period, we must briefly outline the earlier development of the concepts of iustum pretium and proportionality of performances in Roman law and the continental ius commune of the Middle Ages.

$2 C f$ for an outline of the presence of the principle of laesio enormis in the present-day codes of civil law: Piet Abas Benadeling van de medecontractant (Deventer, 2003) and Thomas Finkenauer "Zur Renaissance der laesio enormis beim Kaufvertrag" in Lutz Aderhold et al (eds) Festschrift für Harm Peter Westermann zum 70. Geburtstag (Cologne, 2008) 183-207.

3 JC Voorduin Geschiedenis en beginselen der Nederlandsche wetboeken, volgens de beraadslagingen deswege gehouden bij de Tweede Kamer der Staten-Generaal, V. Deel Burgerlijk Wetboek, art. 1269-2030 (Utrecht, 1838) 141-158 at 147.

4 PW Kamphuisen "De leer van het iustum pretium herleefd" (1933) 3314-3316 Weekblad voor privaatrecht, notariaat en registratie 273-275, 281-283, 289-290; CMO van Nispen tot Sevenaer "De herleving van de leer van den rechtvaardigen prijs en haar rechtswijsgerige grondslag" (1937) 98 Themis. Verzameling van bijdragen tot de kennis van het publiek en privaat recht 1-22.

$5 \mathrm{~J}$ Hijma Mr. C. Asser's handleiding tot de beoefening van het Nederlands burgerlijk recht 5-I (Deventer, 2007) 220-221. For a discussion of the role of proportionality in contemporary Dutch law see, in general, Hallebeek (n 1) and Igor van Loo Vernietiging van overeenkomsten op grond van laesio enormis, dwaling of misbruik van omstandigheden (Rotterdam, 2013).

6 James Q Whitman "The moral menace of Roman law and the making of commerce: Some Dutch evidence" (1996) 105 Yale Law J 1841-1889. I thank Konstantin Tanev (Faculty of Law, Sofia) who at the 67th session of the Société international Fernand de Visscher pour l'Histoire des Droits de l'Antiquité (Sept 2013, Salzburg, Austria) called my attention to this article. 


\section{The iustum pretium rule: Origin and ius commune of the Middle Ages}

\section{Origin}

The iustum pretium rule originates in the Corpus iuris civilis. On the one hand, Roman law acknowledged that buyer and seller were free to agree on a certain price. In negotiations, it was permissible to be guided by self-interest. Parties might even "circumvent" each other. ${ }^{7}$ On the other hand, the fourth book of Justinian's Code contains provisions limiting the possible discrepancy between the value of the merchandise and the selling price. The most important of these for later developments is C 444 2, a rescript of Emperor Diocletian (ca 244-316) dating from the year 285. The original meaning and purport of the text and the circumstances prompting Diocletian to issue the constitution are disputed, and depend largely on the assumption of interpolations. ${ }^{8}$ In all probability, the compilers of the Code partially interpolated the original text and subsequently adopted it in a title dealing with rescission of sale contracts. According to some scholars, the reason for adopting the text in its Justinianic form would have been that, as a result of the tax policy of Justinian ( $\mathrm{ca}$ 482-565), many small farmers were compelled to sell their land and had to be protected economically against the wealthy urban merchants who desired to purchase their land as cheaply as possible. However, this view has been questioned. ${ }^{9}$ The constitution of Diocletian, in its Justinianic wording, ruled that if the selling price of a plot of land was less than half the "fair price" (iustum pretium), the magistrate might rescind the sale on the ground of extreme prejudice (laesio enormis). In such a case, the buyer was entitled to uphold the contract by making an additional payment, namely the shortfall between the selling price and the fair price.

Impp. Diocletianus et Maximianus AA. Aurelio Lupo. Rem maioris pretii si tu vel pater tuus minoris pretii distraxit, humanum est, ut vel pretium te restituente emptoribus fundum venditum recipias auctoritate intercedente iudicis, vel, si emptor elegerit, quod deest iusto

7 D 44164 speaks about circumvenire; D 192223 about circumscribere.

8 See, eg, HT Klami “Laesio enormis in Roman law?” (1987) 33 Labeo 48-63; AJB Sirks "Diocletian's option for the buyer in case of rescission of a sale. A reply to Klami" (1992) 60 Tijdschrift voor Rechtsgeschiedenis 39-47.

9 For a survey, see AJB Sirks "La laesio enormis en droit romain et byzantine" (1985) 53 Tijdschrift voor Rechtsgeschiedenis 291-307, who merely considers C 4442 as allowing the buyer to make a supplementary payment in case of restitutio in integrum; AJB Sirks "Laesio enormis und die Auflösung fiskalischer Verkäufe" (1995) 112 Savigny Zeitschrift für Rechtsgeschichte Rom Abt 411-422; Martin Pennitz "Zur Anfechtung wegen laesio enormis im römischen Recht" in Martin Schermaier et al (eds) Iurisprudentia Universalis, Festschrift für Theo Mayer-Maly (Cologne etc, 2002) 575-589; AJB Sirks "Laesio enormis again” (2007) 54 Revue Internationale des Droits de l'Antiquité 3 e s 461-469. 
pretio recipies. minus autem pretium esse videtur, si nec dimidia pars veri pretii soluta sit. PP v.k. Nov. Diocletiano A. II et Aristobulo conss. ${ }^{10}$

\section{Iustum pretium and the doctrine of restitution}

The medieval scholars of Roman law, the civilians, believed the Corpus iuris civilis should be what Justinian had intended it to be in his introductory constitutions. His legislation should be coherent and consistent and contain no contradiction whatsoever. ${ }^{11}$ For this reason, the civilians interpreted the constitution of C 4442 apart from both the context in which Diocletian issued it and the socio-economic circumstances which may have prompted the compilers to adopt it in the Code. In their approach, it was a provision in a code of law like all other provisions in the Digest and Codex. This approach is reflected in the Accursian Gloss, for example. In D 45136 it was stated that the exception of fraud (exceptio doli) might even be brought if there was no fraud (dolus) on the part of the stipulator, but the matter itself was intrinsically fraudulent (sed ipsa res in se dolum habet) and a claim was subsequently brought on the basis of this stipulation. The Accursian Gloss explained this kind of "fraud", which is present in the matter itself (dolus re ipsa) as follows:

gloss dolum habet ad D. 451 36: Qui proprie non potest dici dolus, sed ipsa res iniqua est, ut si sine causa promiserit totum, uel pro parte stipulatus sum rem quam minus emi dimidia iusti pretii, superueniente ut supra de excepione doli Apud Celsum $\S$ Labeo (D. 4444 7) et 1. ii $\S$ Item quaeritur (D. 44424 ). ${ }^{12}$

Now, this gloss to D 45136 clearly refers to the rule incorporated in C 4442. From the perspective of the Gloss, considering D 45136 and C 4442 simply as provisions of one and the same code of law, promulgated approximately at the same time by Justinian, this makes sense. However, from the more historical perspective of the humanist jurists, the constitution issued by Diocletian in the year 285 could certainly not have featured in an opinion of the jurist Ulpian $(\uparrow 223)$ who must have died about sixty years before that. A fine example of such criticism may be found

10 Translation: The illustrious emperors Diocletian and Maximian to Aurelius Lupus. If you or your father alienated something of a lower value at a higher price, it is human that you will either through intercession of the authority of the court and after restoring the price to the buyers, recover the tenement sold, or, if the buyer would prefer this, will receive what is lacking in the true value. The price, however, is considered to be too low, if not even half the true value has been paid. Promulgated on 28 October, during the second consulate of the emperor Diocletian and the consulate of Aristobulus.

11 Constitution Deo auctore $\S 8$.

12 Translation: Which you actually cannot call fraud, but the matter itself is iniquitous, as when someone without a cause promised the whole or I stipulated for a part the thing which I bought for less than half of the fair price or give the example of the later occurring fraud, as in D 44447 and D 44424 . 
in a monograph on laesio enormis by the Portuguese humanist jurist Arias Piñel (1515-1563). He maintained that the Accursian Gloss and the commentators had been talking gibberish.

Arias Piñel, Commentarii ad rub. et l. II Cod. de rescindenda venditione, Prima pars legis secundae, caput 1, n. 8 .

Putarunt hucusque glossa et omnes Vlpianum in dicto paragrapho respexisse ius huius legis et inde apud omnes inualuit frequentissima allegatio dictae legis qua laesionem ultra dimidiam appellant dolum re ipsa, ad differentiam doli ex machinatione. Ego uerius puto doctores cum glossa ad uerbos iurisconsulti hallucinatos fuisse, nihilque minus iurisconsultum in lege ea (D. 45 1 36) sensisse quam de remedio huius legis quod euincitur ex eodem Vlpiano et aliis iurisconsultis in locis supra citatis, dum aperte et indistincte tradunt, laesis in precio nullatenus succurrri, nec dolum ex sola laesione censeri. ${ }^{13}$

Below, we shall return to the distinction that the medieval scholars drew between two categories of fraud; and especially to the concept of dolus re ipsa, which is also discussed in the gloss quoted. By now, it will be clear that the civilians, glossators and commentators, interpreted the constitution of C 4442 as if independent of any historical context, but in reality could not dissociate themselves from the socio-legal environment of their own time, which was largely determined by canon law and the competence dispute between secular and ecclesiastical jurisdiction. From the beginning of the thirteenth century, canon law was influenced by the theological teachings on restitution, although this doctrine was primarily intended for the forum internum, that is the realm of conscience.

The Church taught that every infringement of the natural order should be rectified by restitution. Infringement was a broad notion. In human intercourse, not only did it cover all extra-contractual damage or enrichment at the expense of another, but also upsetting the balance in contractual relationships, for example by

13 Translation: Thus far the Gloss and all the doctors were of the opinion that Ulpian in this paragraph (the last lines of D. 45136 ) is referring to the right set out in this provision (C. 4442 ) and hence among all of them the frequent allegation of this provision gathers weight. On the ground of which provision, they call the prejudice amounting to more than half (of the fair price) fraud in the matter itself (dolus re ipsa) as distinct from fraud resulting from slyness (dolus ex machinatione). I think, more correctly, that the doctors together with the Gloss talk gibberish as regards the words of the jurist and that the jurist in this provision (D. 45 1 36) pronounces upon nothing else but the remedy of this provision, which is elucidated from the same Ulpian and other jurists in the texts quoted above, while they maintain clearly and without any distinction, that there is no rescue whatsoever for those prejudiced in the price and they do not consider something to be fraud solely because of prejudice. See Arius Pinellus Ad rubricam et legem II Codicis de rescindenda venditione ... commentarii (Frankfurt, 1614) 141-142. See, on these teachings of Arias Piñel, also Justo García Sánchez Arias Piñel, Catedrático de Leyes en Coimbra y Salamanca durante el siglo XVI, La rescisión de la compraventa por laesio enormis (Salamanca, 2004) and Wim Decock Theologians and Contract Law. The Moral Transformation of the Ius Commune (ca. 1500-1650) (Leiden/ Boston, 2013) 572-581. 
breach of contract or enforcing unjust agreements. Initially, the duty of restitution was based on an extensive interpretation of the Biblical commandment not to steal, but from the thirteenth century onwards, it was increasingly connected with the concept of commutative justice, derived from Aristotle's Ethics, which by that time had become known in the West in its Latin translation. Commutative justice required that in reciprocal agreements the performances should balance each other. If the balance was disturbed, it had to be restored.

There were clear differences between the legal rule of C 4442 and the theological doctrine of restitution which was in force in the forum of the conscience. The iustum pretium rule related only to prejudice (laesio) suffered by a seller, which had to be considerable (enormis). The doctrine of restitution related to disproportion in all mutual performances and deemed any prejudice, even if it did not comply with the standard established by Roman law, to be illicit. The theologians referred to both the coherence and the difference between the two principles. According to human law (lex humana) and the law applied by the court (ius fori), it is permissible to prejudice the other party to the extent of half the fair price, although not deliberately or by using tricks, the so-called dolus ex proposito (see below). According to divine law (lex divina) and the law applied in the celestial court (ius poli), any deviation from the fair price is a sin and should be rectified by restitution. In this regard, we may refer to the Summa de animae consiliis of Peter the Chanter (ca 1150-1197) ${ }^{14}$ and the Summa aurea of William of Auxerre (ca 1145-1231). ${ }^{15}$ The difference between the legal standard of Roman law and the moral standard of divine law was clearly depicted by Thomas Aquinas (1225-1274), but from the perspective of medieval scholarship, the difference is one of degree. It is not fundamental. In the case of malicious intent, the forum externum will demand restitution no matter what the extent of the prejudice. If there is only a slight deviation from the fair price, the forum internum will not demand restitution:

Thomas Aquinas Summa Theologiae Secunda secundae q. 77 art. 1 ad 1

(...) Sic igitur habet quasi licitum, poenam non inducens, si absque fraude venditor rem suam supervendat aut emptor vilius emat, nisi sit nimius excessus, quia tunc etiam lex humana cogit ad restituendum, puta si aliquis sit deceptus ultra dimidiam iusti pretii quantitatem. Sed lex divina nihil impunitum relinquit quod sit virtuti contrarium. Unde secundum divinam legem illicitum reputatur si in emptione et venditione non sit aequalitas iustitiae observata. Et tenetur ille qui plus habet recompensare ei qui damnificatus est, si sit notabile damnum. Quod ideo dico quia iustum pretium rerum quandoque non est punctaliter determinatum, sed magis in quadam aestimatione consistit, ita quod modica additio vel minutio non videtur tollere aequalitatem iustitiae. ${ }^{16}$

14 See Karl Weinzierl Die Restitutionslehre der Frühscholastik (Munich, 1936) at 144.

15 See Herbert Kalb Laesio enormis im gelehrten Recht. Kanonistische Studien zur Läsionsanfechtung [Kirche und Recht 19] (Vienna, 1992) 123. Cf Thomas Aquinas Summa Theologiae II II q 77 arts 1 and 4.

16 Thomas Aquinas Opera omnia (editio leonina) IX (Rome, 1897) 148. Translation: (...) Thus in 


\section{Ecclesiastical practice}

Was the doctrine of restitution also applied in the legal practice of the ecclesiastical forum externum ${ }^{17}$ As stated above, the duty to make restitution was primarily a matter of conscience. Augustine (AD 354-430) had taught that sin would not be forgiven unless what had been taken away was restored (restitutio). Otherwise, repentance would be feigned. This rule was adopted in Gratian's Decree of 1140/45 (C 14 q 6 c 1 ), but it was not originally applied in ecclesiastical litigation. From two decretals, it appears that the papal chancery preferred to apply Roman law. The first decretal was Cum dilecti of Alexander III ( $† 1181)$, dating from 1170; the second was Cum causa of Innocent III (c 1160-1216), dating from 1208, and both were eventually adopted in the Liber Extra (X 3173 and X 317 6). The cases and decisions show similarities. In the first case, the canons of Beauvais had sold part of a stretch of woodland to a monastery for less than half the fair price. In the second case, the steward of the monastery of San Martino del Monte had sold certain feudal estates to citizens of Viterbo for less than half the fair price. The wording "for less than half the fair price" was reminiscent of C 4442 , and the constitution's influence was clearly perceptible in the two papal decisions. The buyers were permitted to uphold the contract by making an additional payment up to the amount of the iustum pretium. It was not uncommon for the papal chancery to apply Roman law, as it did here; the reason being the lack of proper canon law standards. Apparently, the doctrine of restitution was not yet considered fit to be applied directly in the forum externum.

However, from the thirteenth century onwards it began to infiltrate ecclesiastical litigation. A decretal of Innocent III, dating from 1204 (decretal Novit ille, in the Liber Extra X 21 13), authorised ecclesiastical courts to deal with anyone committing a sinful act. For this purpose, a specific proceeding was instituted, the denuntiatio evangelica. The doctrine of restitution, which related primarily to the realm of conscience, could consequently infiltrate the forum externum. The ecclesiastical

this way it is considered permissible and no punishment is imposed if a seller without any fraud sells his goods for more or the buyer buys it for less, unless the difference is disproportionate, because then human law also requires restoration, for example when someone is "deceived" into paying more than half the fair price. However, Divine law leaves nothing unpunished that is contrary to virtue. Hence, according to Divine law it is considered unlawful when in buying and selling the consistency of justice is not observed. And the one who has too much should restore to the prejudiced party in a case where the loss is significant. The reason I say this, is that the fair price of things can sometimes not be exactly determined, but rather consists, in a certain assessment, of such a nature that a moderate gain or loss does not seem to cause an imbalance in justice.

17 James W Baldwin The Medieval Theories of the Just Price. Romanists, Canonists, and Theologians in the Twelfth and Thirteenth Centuries [Transactions of the American Philosophical Society, New series vol 49, part 4] (Philadelphia, 1959); KS Cahn "Roman and Frankish origins of the just price of medieval Roman and Canon law" (1969) 6 Studies in Medieval and Renaissance History $3-52$. 
courts were thus able to assist the prejudiced party in more instances of unbalanced performance than secular courts using the iustum pretium rule of C 4442 .

\section{The ius commune: From the iustum pretium rule to the principle of proportionality}

The civilians were in a quandary: Should they admit that Roman law had no means of coming to the aid of the prejudiced party except when immovable property was sold for less than half the fair price, while the ecclesiastical courts with their doctrine of restitution were able to do so? Alternatively, should they misinterpret the Roman texts and so demonstrate that the Corpus iuris civilis could also offer the desired remedy? They often chose the latter option without, however, disclosing their underlying motives. In the secondary literature, this approach is aptly described as "saving the face of Roman law". ${ }^{18}$ From the outset, Roman-law scholarship was no academic Spielerei. Long before the large-scale reception of Roman law, the Corpus iuris civilis was already being interpreted with a view to adopting the texts as living law.

The extensive interpretation of the Roman iustum pretium rule in medieval legal scholarship was in truth a transformation of this rule into a principle of proportionality of mutual performances. It may be seen as an attempt to bring Roman law into line with what were then the standards of canon law. It should be noted, however, that this did not result in identical standards. The differences so meticulously described by the early scholastic theologians mentioned above were only partially eliminated. The Roman iustum pretium rule still tolerated moderate prejudice, at least as long as there was no malicious intent on the part of the party concerned, whereas the obligation of restitution would always demand full recovery. The interpretation of the Roman rule was extended in various ways. Firstly, the text of C 4442 was interpreted so as to provide a remedy not only to the underpaid seller, but also to the buyer who had paid too much. The remedy was by now named after the opening words of the constitution, namely condictio ex lege rem maioris. Obviously, the question arose by how much the price paid should exceed the fair price. The Corpus iuris civilis did not answer this question, and the glossators were divided in their views. Eventually they agreed that the buyer should have paid at least fifty per cent more than the fair price. Secondly, C 4442 was applied to the sale of not only immovable property, but also movables. In the third place, the rule of C 4442 was applied to contracts other than sale, initially those resembling sale, such as lease and barter, and in the thirteenth century to all contracts of good faith and subsequently even to those of strict law. ${ }^{19}$

18 Gero Dolezalek “The moral theologians' doctrine of restitution and its juridification in the sixteenth and seventeenth centuries" (1992) Acta Iuridica (Essays in Honour of Wouter de Vos) 104-114 at 105 .

19 See, also, Reinhard Zimmermann The Law of Obligations. Roman Foundations of the Civilian 


\section{Dogmatic distinction and terminology}

From the gloss dolum habet ad D 45136 and the fragment of Arias Piñel, both quoted above, it appears that medieval scholarship distinguished between two kinds of fraud (dolus). On the one hand, there was fraudulent behaviour on the part of the other party, thus an act of deceit with malicious intent. This was subjective, intentional fraud, namely fraud in the proper sense of the word. It was termed dolus ex proposito or dolus ex machinatione. On the other hand, there was the "fraud" inherent in the merchandise itself, which disadvantaged the one party, but was not necessarily caused by an act of deceit on the part of the other party. This was objective, factual "fraud", in the Gloss termed dolus re ipsa. D 45136 provided the proof of the existence of such a category of dolus, and the gloss dolum habet to this text explained the improper use of the term: "in a proper sense this cannot be called fraud (qui proprie non potest dici dolus)." The remedy of C 4442 was believed to provide protection against such a type of "fraud" (dolus re ipsa). The "fraud" in case of laesio enormis, which merely comprised a considerable deviation from the just price, was nevertheless termed dolus. In English it is difficult to describe this type of dolus in terms of deceit or fraud, but in other languages it can be easier. In Dutch we speak about "een deceptie", in Afrikaans one speaks of "bedroë uitgekom". Neither expression presupposes active fraud by a wrongdoer. Accordingly, the use of terms such as "fraud" (dolus), "to deceive" (decipere) and "deceived" (deceptus) in the writings of the ius commune can be misleading. The context should always show whether they refer to subjective, intentional dolus (ex proposito) or objective, factual dolus (re ipsa).

This having been said, it should be noted that the "circumventing", which was allowed according to D 19222 3, was not interpreted in the Gloss as an act of intentional fraud (dolus ex proposito) but as "fraud" in the matter itself (dolus re ipsa). According to the Gloss, the "circumventing" that Roman law allowed in trade was not a type of active deception.

gloss quemadmodum circumscribere ad D. 192223 (...) Item hoc intellige dolo non interueniente ab aliqua parte et sic improprie dicitur circumuentio uel deceptio (...). ${ }^{20}$

Similarly, the Gloss interpreted very narrowly the statement in D 44164 that "circumventing" is permitted according to nature (naturaliter). Firstly it stated that "according to nature" means "according to the law of nations", since despite the "circumventing" the contract is not void. Subsequently a distinction was drawn between dolus ex proposito and dolus re ipsa. The two kinds of "fraud" had different consequences. In dolus re ipsa, that is, "fraud" without malicious intent on the part

Tradition (Cape Town, 1990) 259-270.

20 Translation: Likewise, understand this as without any fraud coming from one of the parties, and thus improperly called circumvention or deceit. 
of the one party, the "circumventing" was not absolutely prohibited but severely restricted. Minors were fully protected, while those who had reached majority were protected to a certain extent, namely whenever the "fraud" exceeded half the fair price. In the case of dolus ex proposito, where fraud comprised malicious acts by one party, the wrongdoer could be sued on the contract, when the fraud was incidens, namely when the error concerned certain incidental features of the contract (accidentalia), thereby leaving the contract intact (dolus incidens). The case of error concerning the essentials (essentialia) of the contract (dolus dans causam contractui) was not addressed in this gloss, but it would render contracts of good faith null and void and invalidate contracts of strict law by means of a defence.

the gloss naturaliter licere ad D. 44164 id est de iure gentium (...); tenet enim contractus nihilominus; sed deceptus, si quidem re ipsa, minor restituitur pro leui damno etiam, non pro minimo (...) maior non, nisi ultra dimidiam iusti pretii sit deceptus (...). Si autem ex proposito, incidenter tamen agitur ex ea contractu (...). ${ }^{21}$

\section{Roman-Dutch law}

In early modern times there was a fairly general reception of the iustum pretium concept, commonly with a broad application of C 4442 , as defended by the medieval civilians. This also holds good for Roman-Dutch law. In his Inleidinge tot de Hollandsche rechtsgeleerdheid (published 1631), Hugo de Groot (1583-1645) acknowledged the existence of the iustum pretium rule in the Province of Holland. In an "historical" exposition, he explained that the rule was introduced by positive law (the borgherlicke wetten). He argued that the phenomenon of barter had emerged because some people had too much, and others too little, of certain things. As the population grew, some made it their task to collect and redistribute all kinds of goods, thus placing themselves at the service of others. It was therefore reasonable for them to gain a certain profit as a reward for their work. Subsequently, positive law allowed parties to a contract freely to stipulate a certain quid pro quo. After all, it was not easy to place an exact value on the efforts of the merchants, while the value of the merchandise often fluctuated. However, when the merchants' greed started to exceed all moderation and reasonableness, this freedom had to be restricted by protection of the seller through the iustum pretium rule. Practice further extended this protection to the buyer and to other contracts, with the exception of judicial and testamentary sale and sale with the intention of donating. ${ }^{22}$

21 Translation: allowed according to nature this means according to the law of nations (...), because the contract nevertheless holds; but "deceived", at least in the matter itself, a minor will be compensated, also for a small loss, not for a marginal loss (...), but not the one of age, unless he is "deceived" for more than half the fair price (...). However, deceived by intention not affecting the essential terms, one can nevertheless sue on the contract (...).

22 Hugo de Groot Inleidinge tot de Hollandsche Rechtsgeleerdheid 352 1-5. 
That the iustum pretium rule of C 4442 was received in the various provinces of the Dutch Republic, is also made clear in the lecture notes of Jacobus Voorda (1698-1768) on the law of his time. For Gelderland, he referred to provisions of the Statutes, mentioned by Johan Schrassert (1687-1756) in his Practicae observationes. For Holland he referred, apart from the Inleidinge, to De legibus abrogatis (1649) of Simon Groenewegen van der Made (1613-1652) ${ }^{23}$ and the Censura forensis of Simon van Leeuwen (1626-1682), and for Utrecht to the Practyk judicieel of Gerard van Wassenaer (1589-1664). The Decisiones Frisicae of Johan van den Sande (1568-1638) made it clear that the rule was accepted in Friesland. For the validity of the rule in Overijssel and Groningen he referred to various Statutes. This does not mean, however, that there were no differences at all between the provinces. The limitation period of the remedy was not the same everywhere, and there were also differences in exceptions to the rule, namely the types of contracts where appeal to laesio enormis was sometimes not allowed, such as sale at auctions and sale by order of the court. ${ }^{24}$ Scrutiny of the considerations underlying judgments of the Hoge Raad van Holland, Zeeland en West-Friesland, pronounced between 1704 and 1787,25 also shows that the concept of iustum pretium survived into the legal practice of the eighteenth century. Moreover, we also find it even in the very last handbook on civil law edited before the era of codified law, namely the Regtsgeleerd, practicaal en koopmans handboek (1806) of the Amsterdam practitioner Johannes van der Linden (1756-1835) which later served as Code of Commerce in the Transvaal Republic (Zuid-Afrikaansche Republiek) for some time. ${ }^{26}$

Although all this may indicate a strong continuation of the medieval principle of proportionality, Whitman is of the opinion that vernacular books on RomanDutch law show a different approach. According to him, they declared active fraud, denounced by the Christian tradition, to be permissible, thus appealing to Roman law. They relied on Roman law to justify moral behaviour that was otherwise condemned as "unbrotherly". Moreover, this tendency would be part of a revolutionary change in a critical area of Dutch commercial law, which consisted in the abandonment of the long-standing fair-price principles. ${ }^{27}$ In order to demonstrate this, Whitman referred to a treatise on legal practice, entitled Nederlandtsche Practycke, which was written by Bernhard van Zutphen ( $\uparrow 1685)$, an attorney at the Provincial Court of Utrecht. One fragment from this work shows Van Zutphen informing his readers that

23 Simon a Groenewegen van der Made De legibus abrogatis et inusitatis in Hollandia vicinisque regionibus Pars 3 (Nijmegen, 1663) 151-152 (ad C 444 2).

24 Jacobus Voorda Dictata ad ius hodiernum (ed Margaret Hewett vol 1 654) ad D 185 § 1.

25 Christian Brom Urteilbegründungen im „Hoge Raad van Holland, Zeeland en West-Friesland“ am Beispiel des Kaufrechts im Zeitraum 1704-1787 [Rechtshistorische Reihe, 377] (Peter Lang, Frankfurt am Main etc, 2007) 234-246.

26 Joannes van der Linden Regtsgeleerd, practicaal en koopmans handboek (Amsterdam, 1806) at 160.

27 Whitman (n 6) at 1844, 1853-1854. 
they were permitted to trick others in any measure. Moreover, this fragment, just like other vernacular literature on legal practice, breathed an "air of chill immorality". ${ }^{28}$

Bernhard van Zutphen Nederlandtsche practycque van verscheyden daghelijcksche soo civile als criminele questien (Utrecht, 1636) 42:

V. Parthyen contrahenten moghen malcander wel bedriegen in het handelen als maer het bedroch niet en zy boven de helfte van de rechte weerde: Dan so yemandt bedrogen is in de quantiteyt van het goedt alsdan mach hy ageren tot supplement alhoewel het bedroch is beneden de helfte van de rechte prijse (...). ${ }^{29}$

VI. Den vercooper wordt geseydt in bedroch te wesen indien hy verswijght eenige qualiteyt van het goet dewelcke soo hy gheexpresseert hadde den cooper niet en soude gecontraheert ghehadt hebben; ende wort daeromme sodanigen coper ghesuccurreert (...). ${ }^{30}$

The quoted fragment starts with the statement that "circumventing" in trade is allowed. This is more or less what is stated in D 44164 and D 192223 . Subsequently three exceptions are mentioned. The first consists in observing the rule on laesio enormis (C 444 2). The prejudiced party has a remedy where the detriment exceeds half the fair price. Secondly, there is the prejudice resulting from error regarding the quantity of the merchandise. Here the prejudiced party can claim additional performance irrespective of the scope of the detriment. This seems to be the principal rule in the Digest. ${ }^{31}$ The third exception has to do with error concerning the quality of the merchandise. The words "dewelcke soo hy gheexpresseert hadde de cooper niet en soude gecontraheert ghehadt hebben" indicate two things: A malicious concealment of defects and a mistake concerning the essentials of the transaction. In terms of the ius commune the malicious concealment implies a dolus ex proposito. Because the buyer's mistake concerns essential contractual terms the deceit is dolus dans causam contractui. ${ }^{32}$

But did Bernard van Zutphen concede that parties to a contract might generally use tricks? Firstly, we have to realise that his discussion of "circumventing" and "fraud" was not exhaustive. He did not discuss the situation where there was only dolus incidens on the part of the buyer of defective merchandise. He did not refer

28 Idem at $1870-1871$.

29 Translation: V. Parties to the contract may hoodwink each other in their negotiations, as long as the deceit does not exceed half the fair value. If such a person is deceived in the quantity of the thing, he may claim supplement up to the just value, although the "deceit" does not exceed half of the just price.

30 Translation: VI. The seller is said to be deceiving if he conceals a quality of the thing, which would have prevented the buyer from entering into the contract, had he mentioned it. For this reason such a buyer is rescued. (...).

31 Cf D 18140 2; D 191 2pr; D 1914 1; and D 212696.

32 For the origin of the concepts dolus dans causam contractui and dolus incidens in Roman law see Andreas Wacke "Circumscribere und dolus" (1977) 94 Zeitschrift der Savigny-Stiftung Rom Abt 184-246 at 236-245. For the meaning in the civilian tradition, see Zimmermann (n 19) at 670-677. 
to the limitation period of the remedy for laesio enormis or the exceptional cases where the rule for laesio enormis did not hold. It is clear, however, that he recognised three major exceptions to the permissibility of "malcander bedriegen". Secondly, his account of exceptions may not be exhaustive, since nothing is said, for example, about the protection of minors. Beyond any doubt, we may say that "malcander bedriegen" was not generally acknowledged here as permissible behaviour. Moreover, it certainly did not set aside the remedy for laesio enormis.

More indications about what the permissible "circumventing" or "malcander bedriegen" may imply may be found in the Censura forensis (1678) of Simon van Leeuwen, one of the few "Old Authorities" who discussed the question specifically.

Simon van Leeuwen Censura forensis (Leiden, 1662) 689 (Pars 1 liber 4 caput 44 n 1)

Quamvis communiter et naturaliter liceat contrahentibus in justo rei pretio se invicem circumuenire, l.16 § 4 ff. De minorib. (D 4416 ) l.37.ff. De dolo. (D 43 37) \&, quod pluris est, minoris emere, aut quod minoris est, pluris vendere, l.22. §. ult. ff. locat. (D 192223 ) l.8. Cod. De Rescind. vend. (C 4448 ). Si nempe sine aperto dolo \& fraude contingat: qui toto jure reprobatur, l. 1. (D 43 1) \& tot. tit. ff. De dolo malo (D 4 3). Si tamen immodica sit laesio, ut, si ultra dimidiam justi pretii in dando aut accipiendo alteruter fuerit deceptus, potest is adversus alterum agere, ut vel recepto pretio rem restituat, vel id quod justo pretio deest, suppleat aut restituat. ${ }^{33}$

What is said in this fragment reveals the meaning of "permissible circumventing", namely recommendations not intended to deceive the buyer (D 43 37), and selling for more than the actual value of the merchandise (D 192223 and C 444 8); but certainly no slyness (calliditas), lies (fallacia) or tricks (machinatio) (D 431 ) fraudulent acts that Van Leeuwen lumped together as "clear fraud and deceit" (dolus apertus et fraus). Accordingly, "se invicem circumvenire" was only permissible when parties abstained from these fraudulent acts. ${ }^{34}$ Such a kind of "fraud" comes close to the dolus re ipsa of the Accursian Gloss. Moreover, permissible "fraud" is anyhow restricted by the general prohibition of fraudulent behaviour as recorded in title D 43.

33 Translation: Although it is for parties to a contract generally and according to nature allowed to circumvent each other as regards the fair price, see D 44164 and D 4337 , and to buy for less what is worth more or sell for more what is worth less, see D 192223 and C 4448 . As long, of course, as this happens without clear fraud and deceit, which is disapproved by all law, see D 431 and the entire title D 43 . However, where there is an immoderate prejudice, as when one of the parties is "deceived" for more than half the fair price in giving or receiving, he may sue the other, so that either the thing is restored when the price is paid back or the shortfall in the fair price is supplemented or made good.

34 See, also, the next line where van Leeuwen used the term "deceived" (deceptus), where the "deceit" simply comprised the selling price deviating immoderately from the just price (dolus re ipsa). 
Van Zutphen's treatment of "permissible circumventing" in contracts is less distinct and clear in this respect, but we should not exclude the possibility that in van Zutphen's view, permissible "fraud" was restricted by the general prohibition against fraudulent behaviour as much as in van Leeuwen's treatise. Extolling the virtues of the merchandise and commercial persuasiveness are allowed; ruse and guile are not. It is certainly not possible to read into van Zutphen's fragment a general licence to use tricks in trading; nor did he devalue or discount the iustum pretium rule. The fact that references to the virtue of justice and deliberations of a moral nature are lacking should not surprise us, for we are dealing here with a legal manual. However, this does not mean that this text exudes an "atmosphere of immorality".

\section{$4 \quad$ Fair-price principles and Calvinistic ethics}

In support of his conclusion that the Dutch abandoned the long-standing fairprice principles, Whitman also turned to handbooks on ethics, written in Dutch by Calvinistic clergymen and intended for mercantile practice. These books dealt with practical legal questions and provided ethical guidelines from a Calvinistic perspective. Before I consider material from these handbooks that Whitman considered, some preliminary remarks are appropriate. We are dealing here with a category of writings which, as a genre, differed fundamentally from the works of the Old Authorities, since these writings did not describe legal norms, but what ought to be done according to moral standards. In that respect they somewhat resembled the confessors' manuals and the handbooks of early modern scholasticism, used in the Catholic regions of Europe, which describe the rules of the forum of conscience. At the same time, there were important differences. In commercial behaviour, Catholics could rely on the expertise of moral theologians and could put their trust in the pastoral care of the Church, which was supposed to hold the power of the keys. Calvinists, on the other hand, had to use their moral handbooks primarily as guidelines. What their conscience dictated was a matter to be determined by their personal relationship with God. This also explains why the Calvinist manuals concentrated on general principles and deliberations on the proper attitude in commercial intercourse. They spoke only briefly of acts that were to be avoided, whereas the Catholic handbooks provided detailed casuistry, prescribing what had to be done in every possible situation and leaving hardly any room for personal reflection. Moreover, in seeking answers to moral questions, the Calvinists primarily looked for biblical starting points and no longer relied extensively on concepts of natural law or the ius commune, as their Catholic predecessors had. What was also absent from the Calvinist manuals was a distinct legal approach towards moral questions, something the Jesuit moral theologians in particular developed from the end of the sixteenth century onwards.

The longstanding fair-price principles might seem to have been rejected in three Dutch commercial handbooks. The first is the "Vrye jaer-merckt voor den volcke 
Zion", published in Amsterdam (1628) by the Frisian reformed minister Adam Westerman ( $\dagger$ 1634). The second is " "t Geestelijck roer van't coopmans-schip", published in Dordrecht (1638) by Godefridus Cornelisz Udemans (1581/82-1649), who was a reformed minister at Zierikzee. The third is the "Oeconomia christiana, ofte christelicke huyshoudinge, bestiert near den reghel van het suyvere Woordt Godts" by the Amsterdam minister Petrus Wittewrongel (1609-1662). It was published in 1655 and reprinted in 1661 . We should firstly study the passages from these writings to which Whitman referred, in order to establish whether these clergymen did indeed reject the fair-price principles, and so deviate considerably from the Catholic moral theologians of their time. These are the relevant fragments.

Adam Westerman Vrye jaer-merckt voor den volcke Zion (Amsterdam, 1628) 70-71 Als nu dese in de Marckten ghecomen zijn vergeten wort by haer de spreucke Pauli dit is de wille Godts, namelijck uwe heylichmaeckinge, dat niemant synen Broeder verdrucke, noch en bedrieghe. Ghelijck alser ghene handelinghen onder den Menschen ghepleecht en werden sonder dat de zonde sich mede daer onder vertoont soo ist dat dat ooc mede in den Coophandel de zonde geoefent wert (...) ofte in den prijs malcanderen te becoopen (...). ${ }^{35}$

Godefridus Udemans 't Geestelyck roer van 't coopmans schip (Dordrecht, 1640) 20 (...) Dese ongherechtigheydt (...) wordt oock ghepleecht (...) met Monopolie, dat is wanneer de Coopluyden tsamen couten om de waren te houden op eenen onbillicken prijs tot last van de goede Gemeynte (...). ${ }^{36}$

Petrus Wittewrongel Het tweede boeck van de oeconomia christiana (Amsterdam, 1661), 605 Daer by wy oock op den gemeenen merckt-gangh moeten letten; also nochtans dat een wijs ende verstandigh oordeel naer gelegentheyt van tijdt ende plaetse de schaersheyt ofte overvloet der selven dese koopmanschappen sal konnen schatten; near het welcke oock het af of op-slaen van den selven prijs rechtveerdelicken magh gematight worden. Dit zijnde near het gemeene spreeck-woort, voor een rechtveerdigen prijs te houden als men sijne waren soo veel als die near het gemeene oordeel waerdigh zijn verkoopt ende datse soo veel waerdigh zijn als sy in 't gemeen verkocht worden. De genegentheyt van dese of gene gierigaert en magh hier niet onbepaelt gevolght worden. ${ }^{37}$

35 Translation: If they reach the market, they forget the statement of the apostle Paul "this is the will of God, namely your salvation, that nobody will oppress or deceive his brother". Just as no acts between human beings take place without including sins, also in commerce sin is committed (...) or by deceiving each other as regards the price (...).

36 Translation: Such an injustice (...) is also committed (...) through monopoly, i.e. when merchants agree to preserve for their merchandise an unjust price level to the detriment of the common good (...).

37 Translation: Because we should also consider the common trade intercourse, yet also, that a sensible and prudent judgement will be capable of assessing the shortage or redundancy of the merchandise itself according to the time and place, which may also justly restrict the increase or decrease of the price. According to the common saying, this means that we consider it to be a fair price, when a person sells his goods for the amount which according to the common opinion corresponds with the value and that these goods have the value they are commonly sold for. The tendency of some miser or other should not be followed indiscriminately. 
These three texts contributed to the discussion of rules that a decent Christian merchant is morally bound to obey. In that context a series of objectionable acts were mentioned, such as tampering with measures and weights and culpably concealing defects, but also selling merchandise at too high a price.

Adam Westerman, physician and minister, was an early representative of the Further Reformation (Nadere Reformatie), a movement that emphasised the enduring influence of the Gospel in all aspects of life. He wrote pietistic manuals, aimed at the spiritual salvation of sailors and merchants. In the fragment quoted above, he referred to the text of 1 Thessalonians 4 verses 3 and 6, which says it is forbidden to oppress or circumvent one's brother. When explaining the meaning of forbidden circumventing in this text, Westerman mentioned, but did not emphasise, unfair pricing which was just one of the many reprehensible acts a merchant should avoid. From this Whitman comprehended that Westerman understood "circumventing", used in 1 Thessalonians 4:6 (Whitman speaks of overreaching), to mean "using tricks", and so did not emphasise fair-price principles. Those principles would accordingly recede into the background, before being discarded. ${ }^{38}$

Earlier in his article Whitman had pointed out that there was a tradition of viewing the text of 1 Thessalonians 4:6 as being in conflict with the text of D 44164 . Both the Latin Vulgate text of 1 Thessalonians 4:6 and D 44164 used the verb circumvenire. ${ }^{39}$ The former stated that circumvenire was prohibited, the latter that it was allowed. Some Catholic authors indeed referred to this contradiction. The Spanish Jesuit Luis de Molina (1535-1600), for example, clearly contrasted the circumvenire of D 44164 with that of 1 Thessalonians 4:6 in its Vulgate translation. ${ }^{40}$ It could well be that Westerman no longer adhered to this tradition. It seems unlikely that the Vulgate Text of the New Testament could have been his starting point. He studied theology at the University of Franeker ${ }^{41}$ and quoted the text of 1 Thessalonians from the Deux Aes Bible of 1562, which was commonly used by the members of the Reformed Church until the middle of the seventeenth century. The translation of the New Testament in this Bible was based on that of Johannes Dyrkinus ( $\dagger$ before 1592), whose own revision of the text was based on the original

38 Whitman (n 6) at 1864-1865.

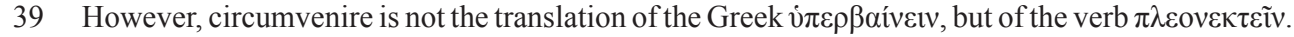
$C f$ Whitman (n 6) at 1859 n 62. Moreover, it is not clear why the circumvenire in the Vulgate text was said to have been used as "a technical Roman contract law term for "overreaching"'. Cf Whitman (n 6) at 1859.

40 Ludovicus Molina De justitia et jure Tom II (Geneva, 1733) at 235 (Tractatus II disputatio $350 \mathrm{n}$ 5).

41 At the Dutch Universities the Latin Vulgata was no longer used in the study of the New Testament. Calvinist ministers were expected to be able to read the Greek text. See HJ de Jonge De bestudering van het Nieuwe Testament aan de Noordnederlandse universiteiten en het Remonstrants Seminarie van 1575 tot 1700 (Amsterdam, 1980) passim. 
Greek. ${ }^{42}$ However, this does not mean that Westerman no longer regarded the text of 1 Thessalonians 4:6 as in conflict with fair-price principles.

Godefridus Udemans, who studied theology in Leiden, is regarded as one of the fathers of the Further Reformation and Calvinistic Work Ethic, according to which working hard is agreeable to God and profiting from trading a sign of God's blessing, but profits should be used to honour God. In listing the things a merchant should avoid, Udemans, as regards fair-price principles focused primarily on monopoly. This may be seen in the fragment quoted above and on the following pages, where Udemans' aversion to monopoly is further elaborated. In this fragment, he based his view on two authoritative texts. The first is Isaiah 5:18, again quoted from the Deux Aes Bible: "Wee den ghenen die hen te samen koppelen, met loosen stricken om onrecht te doen, ende met waghenseelen te sondighen." 43 The second text is C 4591 , the Roman-law prohibition of monopoly. Whitman believed that because in this text fair pricing was discussed with reference to the issue of monopoly only, it showed that the Dutch were discarding the concept of proportionality in contract law and trading.

Petrus Wittewrongel, the third author, also belonged to the Further Reformation. He studied philosophy in Leiden and, compared to the other two, paid greater and more explicit attention to proportionality. He stated that Christian merchants, as a principal rule, should usually contract for a fair price. In addition to the fragment quoted above, Wittewrongel argued that in exceptional cases some deviation from the fair price would be justifiable. Namely, if the seller had to go to great trouble to be able to deliver certain merchandise, or if the seller had to store the merchandise carefully for a considerable period. Whitman suggested that we should read the Wittewrongel fragment with "some literary sensitivity" and compare it to "the fulminations of the non-Dutch literature on price". Then we would see that a critical change was underway. ${ }^{44}$

\section{Conclusions}

There are no grounds to assume that in early modern times legal thinking in Western Europe faced a conflict between the strict standards of traditional Christian morality and the liberal principles of Roman law. It was in its Christianised, Justinianic form that Roman law had penetrated the Western world, and during the Middle Ages, through interpretation and misinterpretation, it had become even more strongly permeated by Christian values. According to the Scripture people ought not to deceive each other in commercial intercourse, and the few scattered texts of Roman law that seemingly stated the opposite were interpreted in a restrictive sense. The permissible

42 Thereby using the Editio Regia (1550) of Robert Estienne (1503-1559).

43 Translation: Woe to those who draw iniquity with false cords, and sin as with cart ropes.

44 Whitman (n 6) at 1866. 
"circumventing" of the Digest was supposed to be considerably limited by various general provisions, such as those concerning fair price, error as regards quantity and quality, protection of minors and, last but not least, the general prohibition against the act of fraud itself. This was the legacy that the "Old Authorities" of RomanDutch law had received from the medieval ius commune. In some ways they may have further adapted this legacy to the world of early modern capitalism, but there is no evidence that in some way they discarded the protection against laesio enormis, based on C 4442 , in favour of a more liberal commercial approach.

Like the "Old Authorities" who had their precursors in the jurists of the medieval ius commune, the Calvinistic ministers who wrote manuals for Christian merchants had their predecessors in the early modern scholastics who wrote about the forum of the conscience. The ministers followed in their footsteps by adhering more strictly to the doctrine of restitution, holding that as a fundamental rule the fair price had to be upheld. In so doing, they did not deviate significantly from their catholic contemporaries. ${ }^{45}$ A comparison of Catholic and Calvinistic writings shows differences, but more in approach than in stringency in upholding norms on fair pricing. The main difference is that the ministers relied almost exclusively on biblical arguments to substantiate their views, and did not discuss moral issues in legal terms. Another difference was that in the case of the Catholic authors their extensive casuistry (are these the "fulminations on price" Whitman spoke of?) almost eliminated the need to consult one's own conscience. At the same time the Catholic authors accepted, as Wittewrongel did, that in certain situations a deviation from the fair price was justifiable.

On the basis of the evidence presented by Whitman it is difficult to construe a clash between traditional Christian ethics on the one hand and Roman law on the other. In addition, we cannot say that vernacular handbooks on Roman-Dutch law and those on commercial ethics show the same tendency of abandoning the longstanding just price-principles. The two differed, but on closer examination, neither displays the suggested tendency. The legal works emphasised the technicalities of legal doctrine and practice, whilst the moral handbooks emphasised biblical provisions and deliberations of a more moral nature. However, that does not mean that the legal works favoured immorality, or that the moral handbooks discarded traditional views on fair pricing. To ensure fair prices, legal works largely followed the traditional legal doctrine on laesio enormis, and moral works the stricter standard of the forum of the conscience. Nevertheless the standards are compatible. The law determined the standard required for peaceful and efficient coexistence, and Calvinistic morality a standard that was in accord with the will of God. It is not surprising that the latter

$45 C f$, the treatment of the just-price requirement in the commercial manuals of Juan de Hevia Bolaño (c 1570-c 1623) and Sigismondo Scaccia (1564-1634). See, too, Juan de Hevia Bolaños Curia Philipica (Madrid, 1790) tom II lib 1 cap 12 n 35 (312) and Sigismundus Scaccia Tractatus de comerciis et cambio (Cologne, 1738) § 1 q 7 par 2 ampl 10 n 41 (226-227). 
set a slightly higher standard. Unfortunately, my findings invalidate Whitman's arguments to some extent. In my view, it is impossible to accept either that in early modern times Roman law was a threat to the moral standards of the time, or that the Dutch, with reference to Roman law, rejected longstanding principles of fair price.

The real attack on concepts of fair price and proportionality was to come from the Schools of Natural Law with their concept of "freedom of contract", which suggested that parties should be free to determine the content of contracts, and not be subject to various restrictions. ${ }^{46}$ At a later stage, this idea culminated in the writings of Christian Thomasius (1647-1713) specifically. This is, however, a new chapter, going beyond the scope of this contribution.

\section{ABSTRACT}

This contribution contains a continuation of an earlier article dealing with the concepts of iustum pretium and proportionality in Roman law and the ius commune. Its findings for Roman-Dutch law, however, appear to be incompatible with the conclusions expounded by James Whitman in an article on the role of Roman law in early modern commerce. Whitman maintained that the traditional Christian rule on fair pricing was no longer upheld by the jurists and clergymen of the Dutch Republic. By appealing to Roman law, the Dutch would have abandoned the longstanding justprice principles and would have considered active fraud by malicious salesmen to be permissible. This would appear from vernacular books on Roman-Dutch law, which, as a consequence, exuded an atmosphere of immorality. Moreover, the new commercial attitude was said to be supported by a number of moral handbooks written by Calvinistic clergymen. However, when reinvestigating the sources quoted from the wider perspective of the civilian tradition, other "Old Authorities" of Roman-Dutch law and the true nature and purpose of the Further Reformation, there is no choice other than to query Whitman's findings. 